\title{
MAGYARORSZÁG VALLÁSFÖLDRAJZI JELLEMZÖI A 21. SZÁZAD ELEJÉN
}

\author{
PETE JÓZSEF
}

\begin{abstract}
Characteristics of geography of religion in Hungary at the beginning of $21^{\text {st }}$ century Our aim is to study the results of the latest census in Hungary and draw conclusions for the religious composition of Hungary in the early years of 21st century. The results show that even though the geographical balance has not changed significantly in the last 10 years, its composition and structure has gone through a serious change. Behind this change, one can suspect the effects of sociological, political and cultural developments that affected the different denominations in different ways. As we study the demographical and geographical data from denominations (Catholic, Reformed, Lutheran) and other groups (other denominations, non-religious, non-respondents) we can discern spatial and sociological changes as well. One of the most conspicuous results is the shifting balance of denominations. Comparing the results of the 2001 and 2011 census, we must ask the question: which one reflects the religious landscape of Hungary more accurately? Which one is distorted and why? Which one is "over-exaggerated"? The answer may be that none of them and the difference lies in the different questioning techniques that lead to different results. As a summary, instead of a "loss of religion", it may be more accurate to speak of a changing attitude to religion, a form of religious individualisation. Religion has not disappeared from the life of individuals, but its roles and expressions have certainly changed, and these are the factors that need to be further researched in the future.
\end{abstract}

A szociológiai vizsgálatok tanúsága szerint Magyarországon - és az egész világon az egyik meghatározó értékrend a tradicionális-vallásos. ${ }^{1}$ Ennek mentalitást, cselekvést befolyásoló szerepe vitathatatlan. Érdemes azonban bemutatni mindennek

${ }^{1}$ Inglehart-Baker: 49. Megjegyzendő azonban, hogy a szekuláris jelleg némileg erőteljesebb (Keller: 10). 
földrajzi dimenzióját is. Különösen fontossá teszi a kérdést a vallásos népesség arányának 21. század elején bekövetkezett csökkenése. Ennek értelmezésére számos magyarázat született. ${ }^{2} \mathrm{Az}$ alábbiakban vallásföldrajzi megközelítésben kívánjuk vizsgálni Magyarország vallási kompozícióját. ${ }^{3}$

\section{MI A VALLÁSFÖLDRAJZ?}

A vallásföldrajz klasszikusnak tekinthető meghatározása: a vallásföldrajz a kölcsönös vallás-tér kapcsolattal foglalkozik, azaz a vallások befolyásával a földrajzi környezetre és fordítva, a természeti, kulturális, szociális és technikai környezet befolyásával a vallási elképzelésekre. ${ }^{4}$ Elsősorban a földrajztudomány és a vallástudomány határterületét vizsgálja, részben azonban az etnográfia, a filozófia, a gazdasági és politikai tudomány határterületeivel foglalkozik. ${ }^{5}$ Felosztását tekintve általános, ágazati, regionális és történeti vallásföldrajzról beszélhetünk.

Az általános vallásföldrajz a kultúra-civilizáció-vallás összefüggésébe ágyazva vizsgálja a vallás és a földrajzi környezet kölcsönhatásait, összefüggéseit (pl. vallás és ökonómia, vallás és ökológia, vallás és demográfia, vallás és politika). Az ágazati vallásföldrajz az egyes vallások földrajzi szemléletű tárgyalásával foglalkozik (földrajzi elterjedés, hitéleti gyakorlat, szervezeti felépítés). Különösen fontos vizsgálati területe az egyes felekezetek etikai előírásai földrajzi vonatkozásainak számbavétele. A regionális vallásföldrajz feladata a földrészek, országok, térségek vallási viszonyainak jellemzése, bemutatása (pl. felekezeti megoszlás, vallások kapcsolata egymással, vallás és környezet). A történeti vallásföldrajz tárgya egyrészt a vallás és környezet történetileg változó kapcsolata, másrészt a vallás történeti változása a térben. Gyakorlati megjelenése az egyes térségek, országok múltbeli vallásföldrajzi viszonyait feltáró munka. ${ }^{6}$

\section{ADATOK, MÓDSZEREK}

Ha a vallást mint társadalmi jelenséget térbeliségében, földrajzi vonatkozásaiban tudományos igénnyel kívánjuk vizsgálni, akkor elengedhetetlen egzakt, „kemény” adatokkal, tényekkel alátámasztani állításainkat. Ha pedig - mint jelen esetben

\footnotetext{
2 A népszámlálás vallási adatainak értelmezését célzó szakmai-publicisztikai írásokat összegzi: Pete (2015): 135-146. Tágabb kontextusban tárgyalja a kérdést: Fodor: 9-22.

${ }^{3}$ A Kárpát-medencei adatok részletes ismertetését történeti kontextusban Kocsis: 9-30.

${ }^{4}$ Rinschede: $20-21$.

${ }^{5}$ Hunyadi: 359 .

${ }^{6}$ Pete (2013): 27-28.
} 
- komplex vallásföldrajzi kép megrajzolására törekszünk, akkor a lehető legszélesebb körü, a vallásföldrajz minden aspektusára releváns adatokat, eredményeket produkáló módszereket kell alkalmazni.

Az adatbázisok, adatforrások alapvetően két csoportra oszthatók: primer (népszámlálások, népmozgalmi adatfelvételek, adatgyüjtések), illetve szekunder források (publikációk, számítások).?

Elsődlegesen az egyes felekezetek híveinek létszámát szükséges térbeliségében megragadnunk. Földrajzilag leképezhető adatbázist az egyes felekezetek, egyházak saját belső felmérései, statisztikái, anyakönyvei jelenthetnek. E kézenfekvőnek tünő adatállomány felhasználása helyett megbízhatóbbnak tűnik (és az alábbi vizsgálat is erre épül ${ }^{8}$ ) a statisztikai felvételek, népszámlálási adatsorok használata, jóllehet ezek is rejtenek problémákat. Különösen élesen jelentkezett ez a 2001 és 2011-es - vallásra vonatkozó - statisztikai felvételeknél.9 ${ }^{9}$

A vallásföldrajznak - mint bármely más földrajzi diszciplínának - sajátos ábrázolási, kifejezési módszere a kartográfiai módszer. Fel kell azonban hívni a figyelmet a felekezeti térképezés problémáira. Azon túl, hogy maga a térkép is eredendően generalizál, a felekezeti térképekre ez a hiba még inkább jellemző. Részben az adatfelvétel esetlegessége, kétes validitása okán, részben az átmenetek, kontaktzónák kevéssé kifejlett ábrázolási metódusai, részben pedig a vallási térképezés ideológiai töltete miatt is így van. ${ }^{10}$

\section{A FELEKEZETI KÉP ÁLTALÁNOS VONÁSAI}

A felekezeti összetétel legjellegzetesebb vonásának az tünik, hogy 2001-hez képest 2011-ben markánsan változott a felekezeti kompozíció: az egyes felekezetek rovására az egyházhoz, felekezethez nem tartozók, illetve a nem válaszolók száma és aránya növekedett. Ha azonban csupán a magukat az egyes felekezetekhez tartozónak vallókat, a válaszadókat vizsgáljuk, akkor némileg árnyaltabb kép rajzolódik ki előttünk: a felekezeti összetétel alig változott. A különbség hátterében feltételezhetôen a vallás(osság)hoz való viszony változása állhatott. ${ }^{11} \mathrm{Az}$ adatok azt mutatják, hogy a térbeli mintázat rajzolata alig, mélysége, szerkezete viszont jelentősen változott a 2000-es években. Ennek hátterében a rendszerváltást követő társadalmi,

\footnotetext{
${ }^{7}$ Becsei: 65 .

${ }^{8}$ 2011-es népszámlálás.

${ }^{9}$ Pusztai: 51-52; Pete (2015): 138-139.

${ }^{10}$ Keményfi: 108-109.

${ }^{11}$ Pete (2015): 135-146.
} 
politikai, kulturális változások nyomozhatók, melyek azonban a különböző felekezeteket eltérő módon érintették.

A felekezeti népesség térbeli rendjében megfigyelhető elsődleges jellemző a településtípusokhoz kötöttség: a településhierarchiában betöltött szereppel ellentétes irányban változik az arány. A településméret tekintetében már nem ennyire egyértelmű az összefüggés. Amíg ugyanis a városok - föleg a 20 ooo fönél népesebb városok - esetében a településméret és a felekezeti népesség aránya közötti összefüggés nem egyértelmü, addig a kisebb városok esetében - éppen úgy, mint a községek esetében is - egyértelmű az összefüggés: a településméret csökkenésével növekszik a felekezeti népesség. Regionális skálán vizsgálva a kérdést az ország középső és alföldi területein átlagos vagy az alatti felekezeti arányt tapasztalunk, míg a Dunántúl nagy részén, valamint Észak-Magyarország területén az átlagot jóval meghaladó értékeket detektálhatunk. Megyei skálán szemlélve az adatokat a Dunántúl-Alföld dichotómiát Szabolcs és Bács magasabb, Baranya és Fejér megye alacsonyabb értéke töri meg.

A 21. századi magyarországi vallási változások egyik legmarkánsabb jellemzője talán a felekezethez nem tartozók számának, arányának növekedése. Megfigyelhető továbbá, hogy területileg is viszonylag jól körülhatárolható tömbben jelennek meg: a Tiszántúl egyes térségeiben alkotnak relatív vagy abszolút többséget, illetve az ország középső sávjában mutatható ki markáns jelenlétük.

A fentiekhez hasonló szembeötlő változás a vallási kérdésre válaszolni nem kívánók számának és arányának megtöbbszöröződése. Ennek okára, hátterére számos magyarázat adódik. ${ }^{12}$ Ugyanakkor ennek a problémának térbeli vetületei nehezen képezhetők le, országos szinten viszonylag kis eltéréseket mutat ugyanis a válaszmegtagadók aránya.

A fenti három felekezeti tömb demográfiai mutatóit részletesebben vizsgálva a nemi összetétel kapcsán megállapítható, hogy amíg az össznépességben 1000 férfira 1106 nő jut, a felekezeti népességben ez 1209, a felekezethez nem tartozóban 993. A különbség szignifikánsnak tekinthető, s megegyezik azzal a megfigyeléssel, miszerint a vallásos népességben a nők felülreprezentáltak.

$\mathrm{Az}$ életkor szerinti összetétel tekintetében is beigazolódnak a várakozások: a vallásos népesség idősebb, mint a nem vallásos. Az öregedési index a teljes népességre vetítve 1,61, míg a történelmi egyházak esetében 2,5. A katolikus és református értékek is e körül mozognak. Ez látszólag cáfolja azt a feltételezést, hogy a vallásilag elkötelezettebbek nagyobb gyerekszámmal jellemezhetőek, így fiatalosabb korösszetételüek. Érdemes tehát az egyes felekezeteket részletesebben megvizsgálni.

${ }^{12}$ Pete (2015): 140. 


\section{A NAGYOBB FELEKEZETEK}

\subsection{KatolikusoK}

A katolikus felekezet Magyarország legnagyobb és egyik legrégibb egyházi közössége. Történelmi egyházként jobbára a vidéki társadalomba ágyazódott be. Ez részben rányomja bélyegét a demográfiai jellemzőkre is. Ezzel kapcsolatban megállapítható, hogy míg az össznépességben a gyerekkorúak és középkorúak aránya a falvakban, addig a fiatal felnőttek és idősek aránya a fövárosban haladja meg leginkább a katolikus átlagot. Ugyanakkor az is elgondolkodtató, hogy a 60 évnél fiatalabb korosztályok esetében az egyes korcsoportok aránya a katolikus népességből a férfiaknál rendre magasabb, mint a nőknél - nem elfeledve persze arról, hogy létszámukat tekintve 30 év fölött már a nők vannak rendre többségben.

A családi állapot kapcsán megállapítható, hogy a férfiak között a nőtlen és házas, míg a nők között az özvegy és az elvált népesség felülreprezentált. A gyermekszám tekintetében kiemelendő, hogy a gyermekek többségének édesanyja házas, az élettársi kapcsolatot megelőzi az özvegy és az elvált családi állapotú is. Figyelemre méltó, hogy a legnagyobb 100 nőre jutó gyerekszámmal az özvegyek rendelkeznek, míg a házasokat az elváltak és az élettársi kapcsolatban élők követik. Ez valószínűsíthetően összefügg a különböző családi állapotú csoportok generációs - és ehhez kapcsolódó reprodukciós mintakövető magatartásának megoszlásával. A 60 év feletti korosztályokban felülreprezentált özvegyek a magas termékenységü korosztályok tagjai voltak, míg a 40 év alatti korcsoportokban felülreprezentált élettársi kapcsolatban élők, valamint hajadonok átlag alatti gyerekszámmal rendelkeznek.

Áttérve a területi vizsgálatokra, elsőként a legnépesebb településeket érdemes számba venni. Ekkor azt tapasztaljuk, hogy a 20 legnagyobb népességü katolikus város többsége ugyan a Duna vonalától nyugatra található, de nagyrészt lefedik az egész országot. A fenti településkategóriák mellett a katolikus népesség eloszlása számossága, széles körü földrajzi elterjedése okán - a legfinomabb, legrészletesebb skálán, a települési skálán is vizsgálandó.

Az ábráról leolvasható, hogy a katolikus népesség (1. ábra) - országos elterjedtsége mellett - alapvetően a Tiszától nyugatra eső területen játszik vezető szerepet. A Tiszától keletre csupán Szabolcsban, illetve a délkeleti peremterületeken található számottevő katolikus népesség. A Tiszától nyugatra viszont Budapesten és tágabb környékén, a Mezőföldön, illetve az Észak-Dunántúl néhány foltján játszik az átlagnál kisebb szerepet a katolikus népesség. A katolikus konfiguráció mintegy komplementer jellegü a protestáns népességgel. Amíg azonban az ország keleti felén inkább a református, addig a nyugati területeken inkább az evangélikus népességgel „egészítik ki” egymást. 
A katolikust a római katolikusok (2. ábra) elterjedésével összevetve csupán anynyi különbséget állapíthatunk meg, hogy Szabolcsban és Borsodban némileg alacsonyabb arány tapasztalható. Nem meglepő módon itt a görögkatolikusok érnek el viszonylag számottevőbb részarányt. Amíg azonban a római katolikusok alig több mint 400 településen nem érik el a $20 \%$-os arányt, addig a görögkatolikusokra (3. ábra) több mint 3000 településen igaz ez. Megyei skálán vizsgálva szembetűnő a katolikus és a római katolikus adatsor paralellitása, melyből a néhány, számottevő görögkatolikus népességgel jellemezhető megye tűnik ki. Regionális skálán talán még egyértelmübb a kép: a görögkatolikusok révén a katolikus és római katolikus arány csak az Észak-Alföldön tér el számottevően egymástól.

\subsection{REFORMÁTUSOK}

A kálvini irány, a református egyház tudományos vizsgálata - annak sajátosan „magyar vallás” jellege folytán - Magyarországon vitán felül áll. Egyben a reformátusok a második legnagyobb felekezete hazánknak.

A demográfiai viszonyokat részletesebben vizsgálva megállapítható, hogy míg az össznépességben a gyerekkorúak és középkorúak aránya inkább a falvakban, addig a fiatal felnőttek és idősek aránya a városokban haladja meg leginkább a református átlagot. A katolikusokhoz viszonyítva tehát nem olyan éles a korosztályok településtípusok szerinti kontrasztja. A férfiak, illetve nők egyes korcsoportokon belüli aránya viszont követi a katolikus mintát. A családi állapotot kapcsán - hasonlóan a katolikusokhoz - a férfiak között a nőtlen és házas, míg a nők között az özvegy és az elvált népesség a felülreprezentált. A gyermekszámot vizsgálva is teljesen a katolikus mintázat képeződik le: a gyermekek többségének édesanyja házas, a hajadon és élettársi kapcsolatban élő édesanyák számát megelőzik az özvegy és az elvált családi állapotúak is; a legnagyobb 100 nőre jutó gyerekszámmal az özvegyek rendelkeznek, míg a házasokat az elváltak és az élettársi kapcsolatban élők követik. A magyarországi reformátusok - demográfiai, településföldrajzi jellemzőik alapján - tehát jól illeszkednek a magyarországi felekezeti - azon belül a történelmi felekezeti - népesség statisztikai trendjeihez. Az összefüggést erősíti az 1000 férfira jutó nők számának (katolikus 1210, református 1218), valamint az átlagéletkor értékének (44,8 év) azonossága. Mindkét esetben a településméret csökkenésével fiatalodik a népesség.

A református népesség néhány sajátos földrajzi, demográfiai jellemzőjének magyarázatát a reformátusság térbeli rendjében kell keresni. Ezt szintén vizsgálhatjuk a legnagyobb református népességü városok térbeli mintázatával. Ebben az esetben az tapasztalható, hogy a Duna és Dráva térségéhez köthető Érd, Székesfehérvár és Pécs kivételével valamennyi a Dunától keletre, fele a Tiszától is keletre található. 
Települési skálán vizsgálva (4. ábra) a református népesség eloszlását, északkelet-magyarországi dominanciája mellett kirajzolódik egy halványabb közép-magyarországi, közép-dunántúli tömb is. Mindezek alapján jól érzékelhető a magyarországi református népesség térbeli súlya, a fentiek alapján pedig a 21. század elején is kimutatható, markáns, földrajzi jelenléte.

\subsection{EvANGÉLIKUSOK}

A Magyarországi Evangélikus Egyház lélekszámát tekintve harmadik, a reformáció óta honos felekezete hazánknak. Átlagéletkoruk magasabb a két történelmi egyházénál, viszont öregedési indexük alacsonyabb. A katolikusoknál valamivel kisebb mértékben ágyazódtak be a vidéki társadalomba, a reformátusokhoz képest inkább nagyvárosiak.

A családi állapot tekintetében a történelmi egyházakhoz hasonló tendenciák érvényesülnek, vagyis a nőtlenek és házasok között felül-, az özvegyek és elváltak között alulreprezentáltak a férfiak. A gyermekszámot vizsgálva megállapítható, hogy az - belső arányait tekintve - követi a katolikus és református mutatókat: a gyermekek többségének édesanyja házas, az élettársi kapcsolatot megelözi az özvegy és az elvált családi állapotú is. Ugyanígy: a legnagyobb 100 nőre jutó gyerekszámmal az özvegyek rendelkeznek, míg a házasokat az elváltak és az élettársi kapcsolatban élők követik. A fentiekhez hasonlóan ez - a már a katolikusoknál és reformátusoknál megismert - különböző családi állapotú csoportok generációs és ehhez kapcsolódó reprodukciós mintakövető magatartásának - megoszlásával állhat összefüggésben.

A magyarországi evangélikusok területi megoszlása (5. ábra) igencsak szórt képet mutat. Történelmi okokból Nyugat-Magyarországon, a Dél-Alföld egyes területein, valamint Nógrádban ér el számottevő arányt az evangélikus népesség. Ennek ellenére legnagyobb népességgel rendelkező városaik - a fenti térségek mellett - a Duna-Tisza közén, valamint Északkelet-Magyarországon is megtalálhatóak.

\subsection{TOVÁBBI FELEKEZETI JELLEMZŐK}

Történelmi-társadalmi jelentőségük folytán érdemes néhány további felekezet jellemzőit is vizsgálni. A magyarországi ortodox népesség 2011-ben 13710 főt tett ki, mely öt nagyobb és több kisebb felekezet tagjaiból álltt. ${ }^{13}$ Ezek közül a legnépesebb

${ }^{13}$ 2015-ben hivatalosan elismert egyházak: Budai Szerb Ortodox Egyházmegye, Konstantinápolyi Egyetemes Patriarchátus Magyarországi Ortodox Exarchátus, Magyarországi Bolgár Ortodox 
a román ortodox egyház, melyet az orosz követ, majd a szerb, görög és bolgár ortodox egyház.

Az ortodox felekezetek demográfiai jellemzőit vizsgálva megállapítható, hogy népessége igen elöregedett, kimagaslóan a görög ortodoxok, de érvényes ez a román és a bolgár ortodox közösségre is. Ezek a kiemelkedő értékek döntően az ortodoxok alacsony számával, illetve szórványhelyzetével magyarázhatók.

Figyelmet érdemel az ortodox felekezetek nemzetiségi összetétele is - ami azonban részben átvezet a területi jellemzők ismertetéséhez is. Kiemelendő, hogy valamennyi felekezet esetében meghaladja a 80\%-ot a magyar nemzetiség aránya, ugyanakkor a szerb, bolgár és román ortodoxok között hasonló arányt képvisel a saját nemzetiségük is. Az orosz ortodoxok „másik” nemzeti identitása megoszlik az orosz és az ukrán között, míg a görög ortodoxoknál a saját nemzetiség „kisebbséget" képez. A leginkább heterogén a más ortodoxok csoportja -érthető módon. Kiemelendő, hogy a nemzetiségi kérdésre válaszolni nem kívánók aránya csupán a más ortodoxok esetében haladja meg az 1\%-ot! Ez a vallási identitásukat őrző ortodoxok nagyfokú etnikai, nemzetiségi elkötelezettségét bizonyítja - mely talán megmaradásuk kettős záloga.

Történelmi-társadalmi jellemzőikből következik térbeli rendjük is, mely szintén nagyfokú szórtságot mutat, különösen települési szinten. Ebben az esetben célszerű járási szinten vizsgálni a jelenséget - és még csak nem is országos léptékben, ugyanis a román ortodoxok túlsúlya miatt az ortodox népesség az Alföld délkeleti szegletében koncentrálódik. Ugyanakkor az egyes ortodox felekezetek elterjedésébe enged bepillantást a regionális skálán történő vizsgálat. Ebből az derül ki, hogy - a román ortodoxok kivételével - valamennyi felekezet esetében a közép-magyarországi régió dominál, a Dél-Alföld és az Észak-Alföld számottevő súlyát a román ortodoxia adja.

A kisebb protestáns felekezetek jelenlétének egyik legfőbb sajátossága a közép-magyarországi koncentráltság. Közülük elsőként a legrégibb, magyar jellegü felekezet, az unitárius említendő. A felekezeti népesség fél százalékát kitevő unitáriusok is a fóvárosban - ahol több mint harmaduk él -, valamint annak tágabb környékén koncentrálódnak; illetve az ország keleti peremén. Erdélyi kötődésüket jelzi továbbá, hogy híveik mintegy 10\%-a román nemzetiségünek vallotta magát.

A baptisták évszázados magyarországi múltjuk és társadalmi-karitatív jelenlétük okán emelhetők ki. Járási szinten kimutatható arányban Közép-Magyarországon, az ország középső sávjában, illetve a keleti határvidéken élnek. Az adventista és pünkösdi közösségek inkább szórt jelleget mutatnak.

Egyház, Magyarországi Kopt Ortodox Egyház, Magyarországi Román Ortodox Egyház, Orosz Ortodox Egyház Magyar Egyházmegyéje (Moszkvai Patriarchátus) (Lelkiismereti). 
Súlyuk, társadalmi jelenlétük révén kiemelendő a Hit Gyülekezete. Híveik főleg Nógrádban és Szabolcsban haladják meg országos arányukat. Számosságát tekintve mind közül leginkább a Jehova Tanúi Egyház emelkedik ki. Országos súlyánál nagyobb arányban a főváros környékén és Északkelet-Magyarországon van jelen.

Mindenképpen említést érdemel továbbá három nem keresztény történelmi felekezet, mely magyarországi jelenlétét tekintve is évezredes, illetve évszázados múlttal rendelkezik. Ázsiai gyökereik, kapcsolataik magyarázzák, hogy közöttük a nemzetiségiek aránya kimagasló: 30-90\%-ig terjed.

$\mathrm{Az}$ eredendően urbanizált magyarországi zsidóság a holokausztot követően területileg, településileg tovább koncentrálódott. Amíg az össznépességen belül a csökkenő lélekszámú településtípusokkal növekedett a lakosság összlétszáma, addig a zsidóság esetében éppen ellenkezőleg: a kisebb lélekszámú településtípusokban a zsidóság összlétszáma egyre csökkent. Hasonló területi koncentrációt figyelhetünk meg regionális bontásban is: Közép-Magyarországon, azon belül Budapesten, a belső kerületekben koncentrálódik. Súlypontjuk is Budapest közigazgatási határain belül található. ${ }^{14}$

A magyarországi iszlám közösség - a kapcsolat történelmi távlatai ellenére gyökerét, bázisát a rendszerváltást követően megélénkülő migráció jelentette. Hazai híveinek zömét azonban a Magyarországon megtértek adják. Szinte kizárólag Budapesten, Debrecenben, Szegeden és Pécsett koncentrálódik.

Végezetül érdemes megemlékezni a magyarországi buddhizmusról is, mely amellett, hogy évszázados múltra tekinthet vissza hazánkban - a szovjet korszakban Kelet-Európában az egyetlen hivatalosan elismert buddhista közösség volt. A rendszerváltást követően egyre sokszínűbb, egyre ismertebb, láthatóbb lett. Legnépesebb közösségei Budapesten, Szegeden, Pécsett, illetve Borsodban és Veszprém megyében élnek.

\section{5. ÖSSZEGZÉS}

A 21. század eleji magyarországi vallásföldrajzi változások legfontosabb trendjeit a felekezetek megyei szinten aggregált mutatóiból számolt felekezeti súlypontok változása mutatta (6. ábra).

A súlypontok jellegzetes nyugat-keleti láncolatot alkottak 2001-ben, mely az evangélikusoktól a görögkatolikusokig terjedt. A fenti mintázatot összehasonlítva a 2011-es adatokkal jókora eltéréseket tapasztalhatunk. Egyrészt ugyanis a láncolat helyett sokkal sűrűbb, halmazszerü tömörülését tapasztaljuk a súlypontoknak: szinte valamennyi súlypont a közép-magyarországi régióban koncentrálódik, míg a korábbi népszámlálás időpontjában csupán alig a fele volt itt megtalálható. Ez

${ }^{14}$ Pete (2016): 329 . 
jelezheti egyrészt a népesség sokkal erőteljesebb központosodását, másrészt a felekezeti „szélsőségek” megszűnését is.

Pontosabb összehasonlítást tesz azonban lehetővé a súlypontok két időpont közötti elmozdulásának koordináta-rendszerben történő ábrázolása. A súlypontok vergenciájának vizsgálatából ugyanis az derül ki, hogy valóban kimutatható a népesség szinte valamennyi szegmensének „keletre tolódása”: minél nyugatabbról indul az adott felekezet, annál jelentősebb a keleti elmozdulása. A legjelentősebb változáson a válaszmegtagadók csoportja ment át, nem véletlen, hogy egyedüliként nyugatra tolódott a felekezeti csoportok közül. ${ }^{15}$

Végigpásztázva a 2001-es és 2011-es népszámlálás vallási adatait, feltehető úgy is a kérdés: melyik adatsor, melyik népszámlálás tükrözi az „igazi” képet Magyarország jelenkori vallási helyzetével kapcsolatban? Melyik „torzít”? Melyik „túlmért"?

Talán egyik sem. Megállapítható ugyanis, hogy a két népszámlálás kérdésfeltevésében vannak különbségek, ${ }^{16}$ melyek a kérdésfeltevés jellegéből is adódóan más eredményt adhattak. A kérdések ugyanis más jelenségre kérdeztek rá: a felekezethez tartozás formális tényén túl a hozzájuk való viszonyt is rögzíteni kívánta a 2011-es cenzus.

Magyarország vallásföldrajzi képének 21. század eleji változásával kapcsolatban helyesebbnek véljük az elvallástalanodás helyett inkább a valláshoz, vallásossághoz való átalakult viszonyról, individualizációról beszélni. Nem a vallás tűnt el az emberek életéből, hanem a vallásosság módja alakult át ${ }^{17}$ - amit azonban érdemes földrajzilag (is) értelmezni. ${ }^{18}$

\section{IRODALOM}

BeCsei József: Népességföldrajz, Békéscsaba, Ipszilon Kiadó, 2004.

FoDOR Zsófia: „Vallásosság a posztmodern korban”, Vallástudományi Szemle XI, 2015/2. 9-22.

HunYADI László: „Általános vallásföldrajz”, in Tóтн József (szerk.): Általános társadalomföldrajz I., Budapest-Pécs, Dialóg Campus, 2002. (Dialóg Campus Tankönyvek)

INGLEHART, Ronald - BAKER, Wayne E.: „Modernization, cultural change, and the persistence of traditional values", American Sociological Review LXV, 2000/1. 19-51. https://www.researchgate.net/ publication/230557601_Modernization_Cultural_Change_and_the_Persistence_of_Traditional_Values (2019. július 18.)

KeLLER Tamás: Magyarország helye a világ értéktérképén, Budapest, TÁRKI, 2009, http://old.tarki.hu/ adatbank-h/kutjel/pdf/b27o.pdf (2019. július 14.)

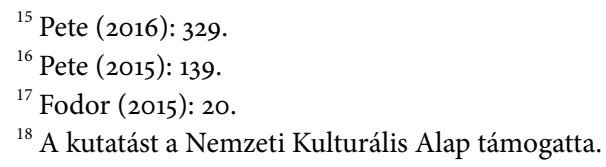


KeMÉNYFi Róbert: Földrajzi szemlélet a néprajztudományban. Etnikai és felekezeti terek, kontaktzónák elemzési lehetőségei, Debrecen, Kossuth Egyetemi Kiadó - Debreceni Egyetem, 2004.

Kocsis Károly: „A Kárpát-medence történeti vallásföldrajza (10-21. század)”, in Gál András - FrisNYÁк Sándor - KóкAI Sándor (szerk.): A Kárpát-medence történeti vallásföldrajza. Tanulmánygyüjtemény. Első kötet. Nyíregyháza-Szerencs, Nyíregyházi Egyetem Turizmus és Földrajztudományi Intézete - Bocskai István Katolikus Gimnázium, 2016, 9-30. http://www.nyf.hu/foldrajz/ sites/www.nyf.hu.foldrajz/files/oktatasi_segedanyagok/konyvek/teljes_bw.pdf (2019. július 20.)

Pete József: „Mi a vallásföldrajz?”, in Csima Ferenc (szerk.): Valláshorizontok. Vallástudományi tanulmányok, Budapest, Favorit Könyvkiadó, 2013, 11-43.

Pete József: „Változások Magyarország vallási «térképén»”, in TÉsıts Róbert - AlPEK B. Levente (szerk.): A mi geográfiánk. Tóth József emlékezete. Pécs, Publikon Kiadó, (Geographia Pannonica Nova, 18.) 2015, 135-146.

PETE József: „A magyarországi protestantizmus néhány vallásföldrajzi jellemzője”, in PAJTóKNÉ Tari Ilona - Tóтн Antal (szerk.): Magyar Földrajzi Napok 2016, Konferenciakötet, VIII. Magyar Földrajzi Konferencia - XVI. Geográfus Doktoranduszok Országos Konferenciája - Oktatás-módszertani és Földrajztanári Konferencia, Eger, Eszterházy Károly Egyetem - Magyar Földrajzi Társaság - Agria Geográfia Alapítvány, 2016, 322-331. https://foldrajzinapok.hu/media/com_acymailing/ upload/MFN_2016_konferenciakotet.pdf (2019. július 20.)

PuszTaI Gabriella: „Felekezeti oktatás új szerepekben”, Educatio XXIII, 2014/1. 50-66.

Rinschede, Gisbert: Religionsgeographie. Das Geographische Seminar, Braunschweig, Westermann Schulbuchverlag GmbH, 1999.

2011. évi NÉPSZÁMLÁLÁS. 10. Vallás, felekezet, Budapest, Központi Statisztikai Hivatal, 2014. http:// www.ksh.hu/nepszamlalas/vallas_sb (2019. július 20.)

A LELKIISMERETI és vallásszabadság jogáról, valamint az egyházak, vallásfelekezetek és vallási közösségek jogállásáról szóló 2011. évi CLXXV. törvény http://kozlonyok.hu/nkonline/MKPDF/hiteles/ MK11166.pdf 


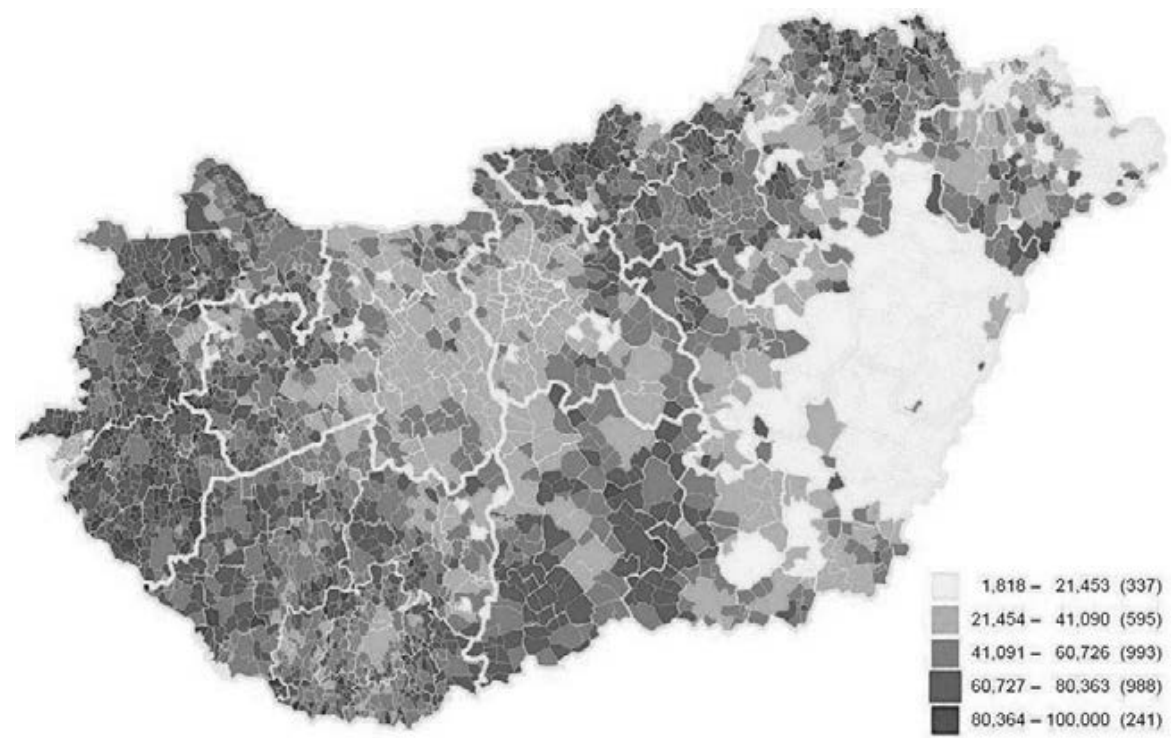

1. ábra: A katolikus népesség aránya településenként, 2011

(Forrás: 2011. évi Népszámlálás)

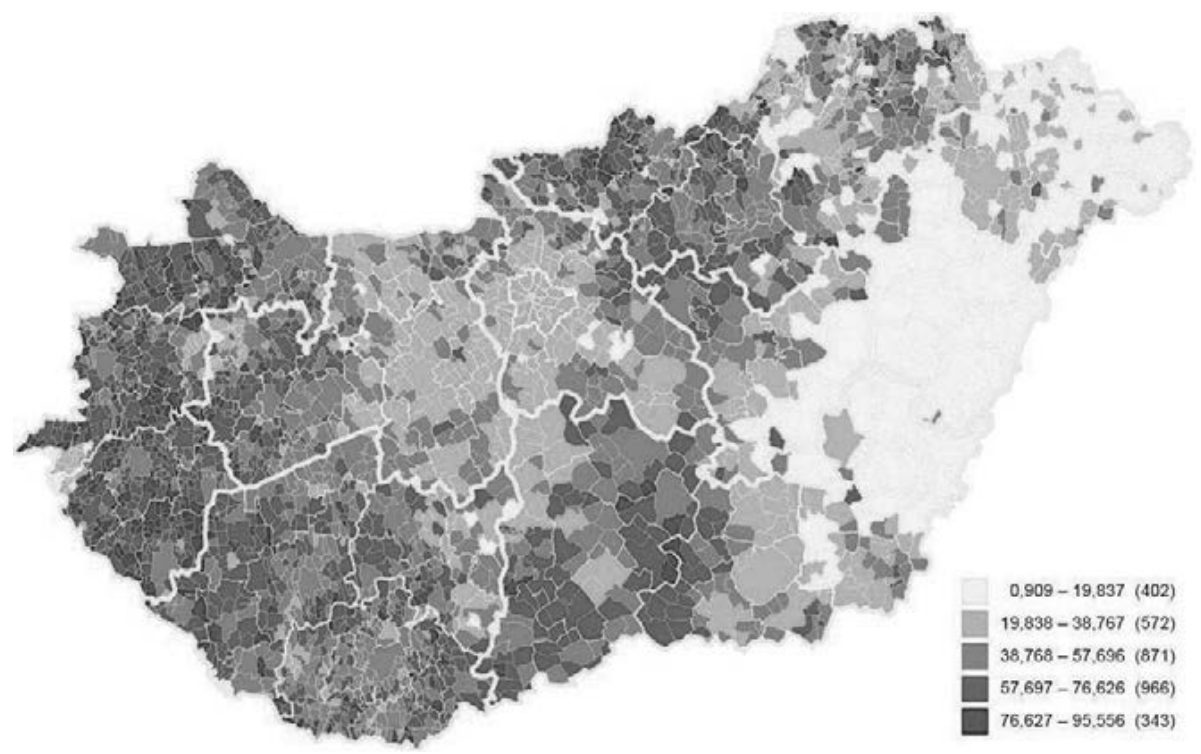

2. ábra: A római katolikus népesség aránya településenként, 2011

(Forrás: 2011. évi Népszámlálás) 


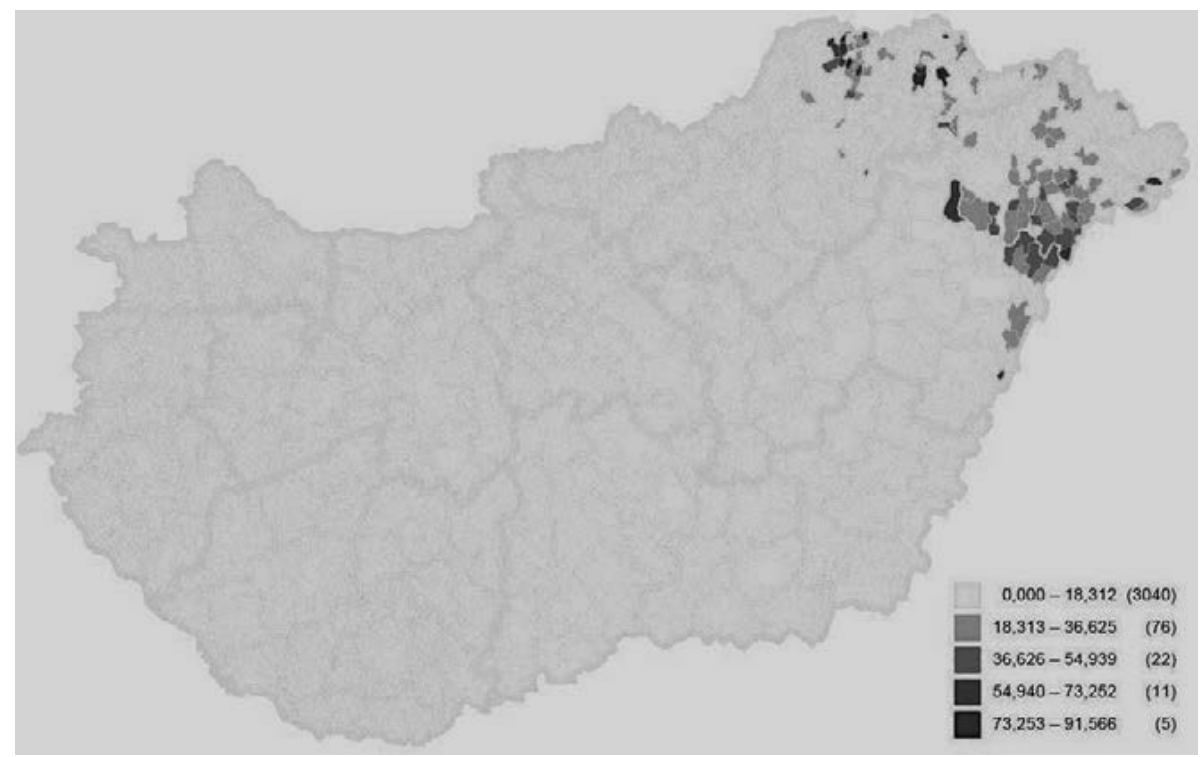

3. ábra: A görögkatolikus népesség aránya településenként, 2011 (Forrás: 2011. évi Népszámlálás)

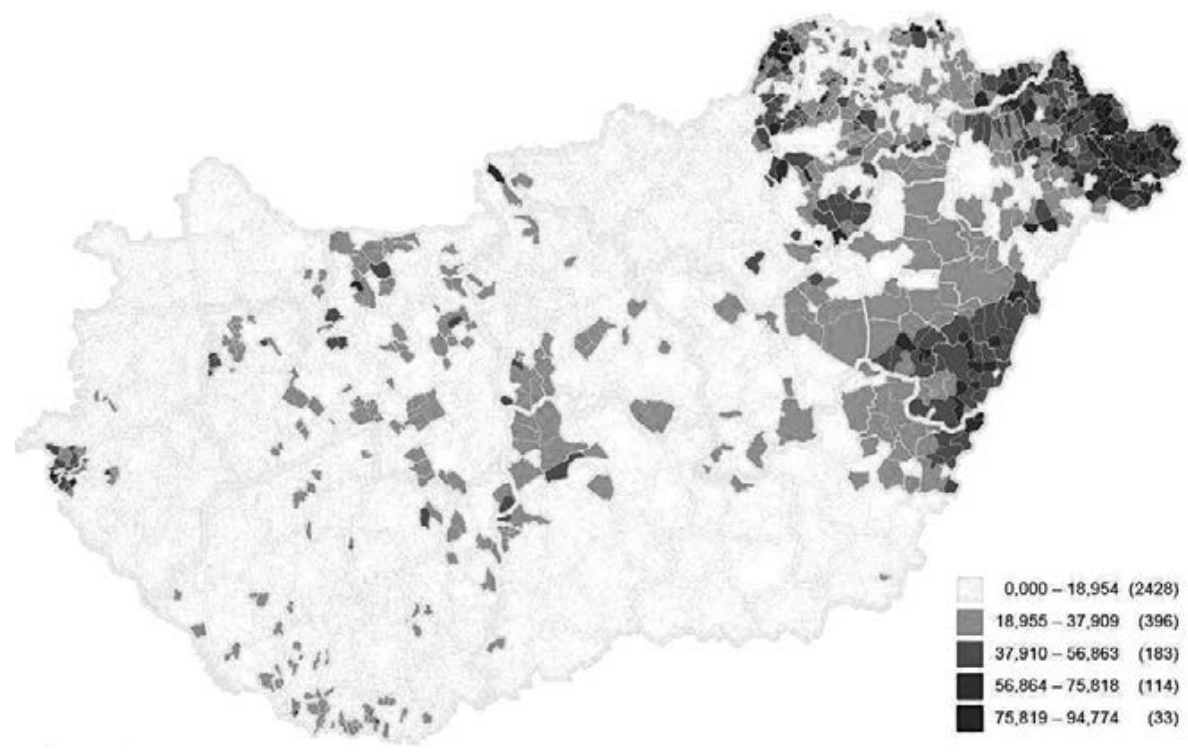

4. ábra: A református népesség aránya településenként, 2011

(Forrás: 2011. évi Népszámlálás) 


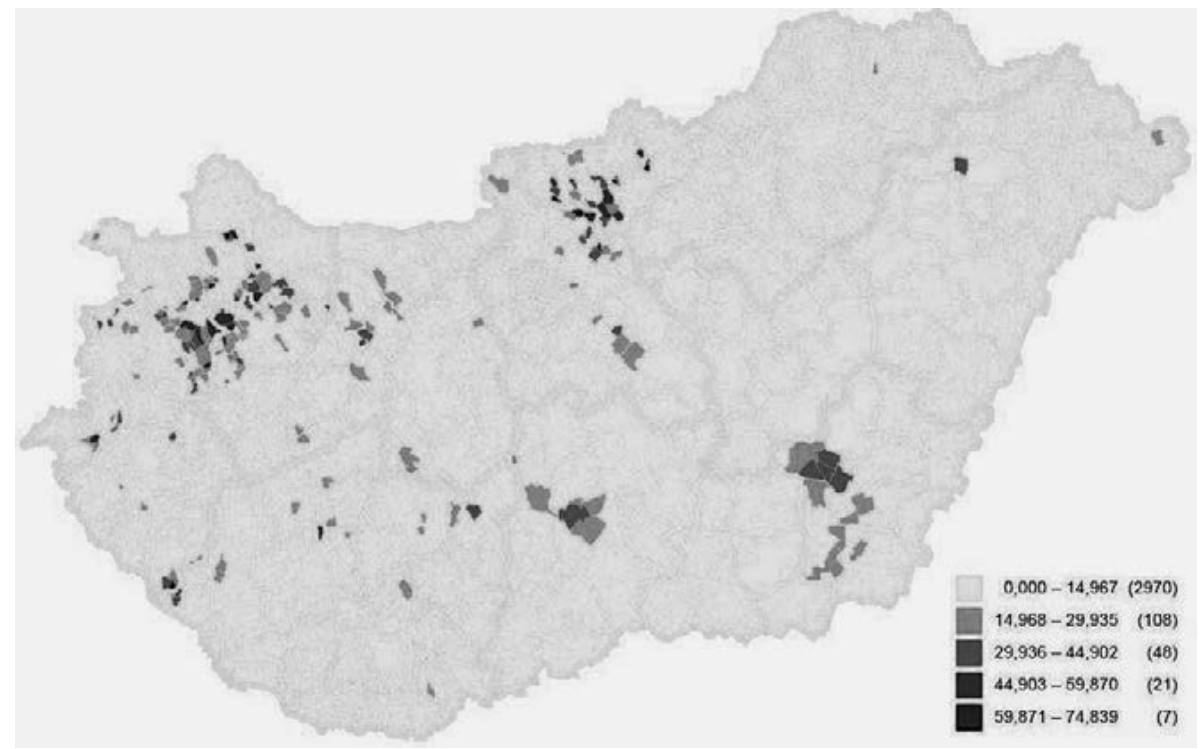

5. ábra: Az evangélikus népesség aránya településenként, 2011

(Forrás: 2011. évi Népszámlálás)

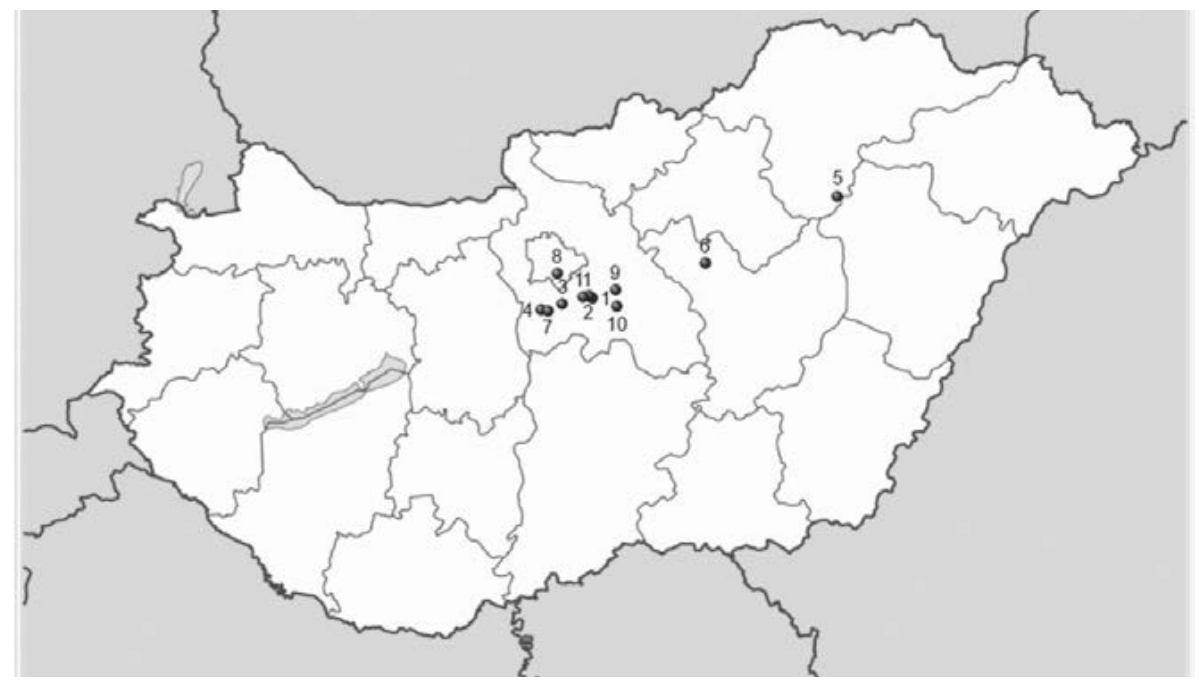

6. ábra: A magyarországi felekezetek súlypontjai, 2011

(Forrás: 2011. évi Népszámlálás alapján, saját szerkesztés)

Jelmagyarázat: 1. Össznépesség, 2. Egyházhoz, felekezethez tartozik, 3. Katolikus, 4. Római katolikus, 5. Görögkatolikus, 6. Református, 7. Evangélikus, 8. Izraelita, 9. Más egyházhoz, felekezethez tartozik, 10. Egyházhoz, felekezethez nem tartozik, 11. Nem kíván válaszolni, ismeretlen, nincs válasz 